
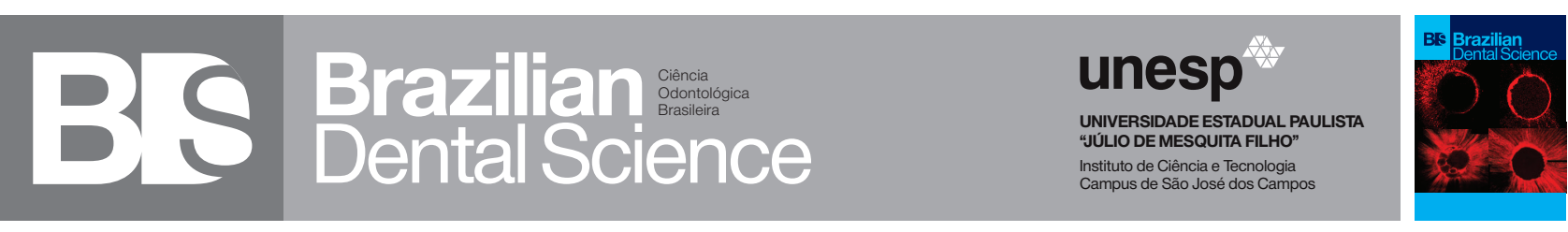

\title{
Contamination of paper points used by students during preclinical and clinical endodontic procedures
}

Contaminação de cones de papel utilizados por estudantes durante procedimentos endodônticos pré-clínicos e clínicos

María del Pilar ANGARITA ${ }^{1}$, Karen Mercedes ANGARITA ${ }^{1}$

1 - Dentistry Program - Universidad Cooperativa de Colombia - Villavicencio Campus - Colombia.

\begin{abstract}
Objective: To determine the presence of facultative anaerobic bacteria in the paper points used by students and to perform a pilot test to determine whether sterilization of these materials influences their absorption capacity. Material and Methods: This study consists of two phases. The first is a descriptive phase where a representative sample of paper points $(n=72)$ was collected from the students and information about the points was voluntarily contributed. The points were placed in saline solution after they were collected, and mechanically shaken for $60 \mathrm{~s}$. Then, $300 \mathrm{IU}$ of the solution was seeded on blood agar in duplicates and incubated for 5 days under anaerobic conditions. The second phase was experimental, during which five paper points of each of the existing sizes were sterilized (Numbers: 15, 20, $25,30,35,40,45,50,55,60,70$, and 80), and their capacity to absorb water was compared with that of the control or non-sterilized points. Results: The study determined that 22\% $(n=16)$ of the points were primarily contaminated by gram-positive bacilli, followed by gram-positive cocci, among which Staphylococcus epidermidis was identified. The presence of contamination was not significantly associated with the conditions of the paper points $(p>0.05)$. Furthermore, no significant effect $(\mathrm{p}>0.05)$ on the absorption capacity of these materials was detected in the sterilization test. Conclusion: Contamination was observed in the paper points used by the students, confirming the importance of implementing sterilization protocols. The sterilization protocols implemented in this study did not affect the absorption capacity of the points.
\end{abstract}

\section{KEYWORDS}

Microbiology, Contamination; Bacteria; Anaerobic.

\section{RESUMO}

Objetivo: Determinar a presença de bactérias anaeróbias facultativas nos cones de papel usados pelos alunos e realizar um teste piloto para determinarse a esterilização desses materiais influencia sua capacidade de absorção. Material e Métodos: Este estudo consiste em duas fases. A primeira é uma fasedescritiva, em que uma amostra representativa de cones de papel $(n=72)$ foicoletada dos alunos e informações sobre os cones foram voluntariamente fornecidas. Os cones foram colocados em solução salina após serem coletadose agitados mecanicamente por 60 s. Em seguida, $300 \mu \mathrm{l}$ da solução foramsemeadas em ágar em duplicatas e incubadas por 5 dias em condições anaeróbicas. A segunda fase foi experimental, durante a qual cinco pontos depapel de cada um dos tamanhos existentes (Números: 15, 20, 25, 30, 35, 40,45, 50, 55, 60, 70 e 80) foram esterilizados e suas respectivas capacidades deabsorção de água foram comparadas com a do controle ou dos cones de papelnão esterilizados. Resultados: O estudo determinou que $22 \%(\mathrm{n}=16)$ dospontos estavam primariamente contaminados por bacilos grampositivos, seguidos por cocos gram-positivos, dentre os quais o Staphylococcus epidermidis foi identificado. A presença de contaminação não foisignificativamente associada às condições dos cones de papel (p\&gt; 0,05). Alémdisso, nenhum efeito significativo (p\&gt; 0,05 ) sobre a capacidade de absorçãodesses materiais foi detectado no teste de esterilização. Conclusão: Acontaminação foi observada nos cones de papel utilizados pelos estudantes,confirmando a importância da implementação de protocolos de esterilização.Os protocolos de esterilização implementados neste estudo não afetaram acapacidade de absorção dos cones.

\section{PALAVRAS-CHAVE}

Microbiologia; Contaminação; Bactérias; Anaeróbias. 


\section{INTRODUCTION}

$\mathrm{P}$ revention of infections is essential to avoid the spread of pathogenic microorganisms which harm the health of patients as well as the inadequate or excessive use of antimicrobial agents [1]. The five moments of hand hygiene, application of biosafety measures, and implementation of aseptic techniques in all procedures are among the measures for preventing infections at health centers [2].

Three basic principles must be achieved during endodontic treatment, which include asepsis [3], biomechanical preparation, and complete canal obturation [4]. The principle of asepsis implies managing with the used of sterilization of instruments and some of the materials which will be placed in the root canal. This avoids transferring microorganisms capable of surviving in the harsh environment of the obturated root canal (such as low oxygen concentration, insufficient or almost null amount of nutrients, limited space, and presence of antimicrobial substances). These microorganisms include facultative anaerobic bacteria which adapt to the absence of oxygen. It has been determined that these bacteria could adapt and cause a new infection if they have an adequate infective dose and virulence factors [5].

Paper points are materials used to absorb moisture after biomechanical preparation during endodontic treatment. It is the last material to be placed in the canal before sealing; therefore, it is important for it to be free of microorganisms at the time of use. The absorbent points are usually made up of cellulose with an added binder which imparts rigidity and prevents it from coming apart during use. Points are sold in assorted packaging of various sizes, diameter, and quantity, and must have the specifications of the International Organization for Standardization (ISO) [6]. Their characteristics include the capacity to absorb any type of fluid; having a uniform length; having a straight point shape; being white and odorless; having sufficient integrity under dry or wet conditions to prevent the release of fibers; and being free of microorganisms [6].

Several studies have reported the contamination of some brands of these materials, even in unopened packages [7-9]. Similarly, different authors have reported contamination when the packaging is opened or contamination owing to inadequate handling [810], which indicates that there may be several causes for this contamination. Therefore, it will be useful to define the possible degree of contamination of these materials to establish standardized sterilization/disinfection protocols, for improving the quality of the processes and results. The aim of this study was to determine the presence of facultative anaerobic bacteria in the paper points used by students at the dental clinics of the Universidad Cooperativa de Colombia, in Villavicencio, and to conduct a pilot study to determine whether sterilizing these materials affects their absorption capacity.

\section{METHODS}

This study was composed of two phases. A descriptive cross-sectional study was conducted in the first phase to determine the presence of facultative anaerobic bacteria in paper points used by students at the dental school and its relationship with the points' characteristics. An experimental study was conducted in the second phase to determine the effect of sterilization on the absorption capacity of the points (Fiure 1).

\section{First phase}

A representative sample of paper points was collected during the first semester of the 2017 from preclinical and clinical students at the UCC, in Villavicencio, with a confidence level of 95\% ( $\mathrm{n}=72$ students). Simple randomization was performed for the selection of students using a list; they were invited to participate and informed consent was obtained. They were also asked to provide a new point and information on the semester they were enrolled in, date on which the package was opened, expiration date, storage type, paper points manufacturer, point number, and whether the point was reported as being sterilized by the manufacturer. Exclusion 
criteria included points provided by students who were not participating in preclinical or clinical sessions and students who did not have the requested information. This study was approved by the University Ethics Subcommitee (Aproval no. 005-2017).

\section{Collection and microbiological analysis of the points}

The points were directly collected during preclinical and clinical sessions, after implementing aseptic conditions when the points were directly taken from the packaging. A Bunsen burner and sterile tweezers were also used to remove the points. The points were then stored in separate sterile bags, which were sealed and kept in an airtight container until the microbiological analyses were performed.

The samples were processed under aseptic conditions for the microbiological analysis in a laminar flow chamber. The points were placed in Eppendorf tubes with $1 \mathrm{ml}$ sterile saline solution. The tubes were mechanically agitated for 1 min using a Vortex (V1 Plus, Boeco, Hamburg, Germany) to release the microorganisms present in the points. Then, $300 \mu \mathrm{l}$ of the solution was inoculated on blood agar in duplicates and incubated for 5 days at $35^{\circ} \mathrm{C}$ in an anaerobic jar containing sachets which induced anaerobic conditions (Anaerogen Thermo Scientific, Oxoid, Waltham, Massachusetts, USA). A point contaminated with saliva was used as a positive control.

The presence of bacterial colonies was determined after incubation of the inoculated blood agar and they were quantified. The results were converted to milliliters of solution for the final quantification. The morphology of the bacterial cells was microscopically determined by Gram staining, and aerobic test was conducted to confirm whether the bacteria were facultative anaerobes. Finally, bacteria with coccus morphology were identified at a certified laboratory using the VITEK system (2 Compact, Marcy-l'Étoile, France).

\section{Second phase}

For this phase, 10 standardized Dentsply Maillefer-brand points (Paper Point, 02, A 022R, Ballauigues, Switzerland) were used. Five of the points were sterilized at $121^{\circ} \mathrm{C}$ for $15 \mathrm{~min}$, and 5 points were used as controls, for each of the different sizes (Numbers: 15, 20, 25, 30, 35, 40, $45,50,55,60,70$, and 80). The initial weight of each point was individually determined on the precision scale (Entris 2241-1S, Sartorius, Göttingen, Germany), and the points were then immersed in water for $30 \mathrm{~s}$. Subsequently, the points were placed on absorbent paper for $10 \mathrm{~s}$ to remove excess water before weighing them again. Finally, the difference in weight before and after immersion in water was determined to compare the absorption capacity.

\section{Statistical analysis}

Mean, median, standard deviation, and variance of the total colony forming units (CFUs) present in the points were determined using version 25.0 of SPSS software (IBM Corp, Armonk, NY, USA). Frequency tables were created for the analysis of qualitative variables; contingency tables and the Chi-squared test were used to establish an association between variables.

During the second phase, the difference in weight before and after immersing the treatment and control points in water was compared to determine the effect of the sterilization on the absorption capacity. The parametric Student's t-test was used based on the normality of the data and variance homogeneity test.

\section{RESULTS}

Characteristic of the paper points collected

Among the characteristics of the points collected from the University clinics, it was determined that the points were most frequently stored in a clinic $(91.7 \%, \mathrm{n}=66)$. The predominant point brand was No. 1 (58.3\%, $\mathrm{n}=42$ ), the vast majority of points were not reportedly sterilized $(95.8 \%, \mathrm{n}=69)$, and most of the points analyzed were No. $15(29.2 \%, \mathrm{n}=$ 
$21)$, followed by No. $35(29.4 \%, \mathrm{n}=14)$ and No. $30(18.1 \%, n=13)$. Moreover, most of the points which were analyzed had been opened for $0-3$ months $(33.6 \%, \mathrm{n}=24)$, followed by 3-6 months $(22.2 \%, \mathrm{n}=16)$ and most had more than 12 months before they expired (63.9\%, $\mathrm{n}$ =46). (Figure 2)

\section{Microbiological analysis}

This study determined that 22\% ( $\mathrm{n}=$ 16) of points were contaminated by facultative anaerobic bacteria, with a median of $30 \mathrm{CFU} /$ $\mathrm{ml}$ (IQR 30-70). The types of bacteria found included gram-positive bacilli (68.2\%), followed by gram-positive cocci $(18.2 \%)$ and gram-positive spore-forming bacilli (13.6\%). The gram-positive cocci were identified to be Staphylococcus epidermidis.

\section{Test to determine the association between point conditions and point contamination}

No statistically significant association was detected between point characteristics and the presence of contamination in this study ( $p>$ 0.05). However, based on the number of points analyzed for each characteristic, most of the contaminated points were those stored in a clinic $(24.2 \%, \mathrm{n}=16)$, belonging to brand No. 3 (25 $\%, \mathrm{n}=12)$. They were also the ones reportedly sterilized by the manufacturer $(33.3 \%, \mathrm{n}=1)$, those belonging to No. $35(50 \%, \mathrm{n}=7)$, those which had been open for 3-6 months (31.3\%, n $=5$ ), and those with no information regarding the expiration date $(100 \%, \mathrm{n}=1)$ (Figure 3$)$.

\section{Second phase: Test to determine sterilization and absorption capacity}

No significant differences were detected between both values in any of the point numbers evaluated when comparing the average obtained for absorption capacity of the sterilized points with that of the control points, which indicates that sterilization did not affect the absorption capacity of points of this brand (Table I).
Table I - Difference in the absorption capacity of paper points belonging to control and treatment groups.

\begin{tabular}{|cccc|} 
Point number & $\begin{array}{c}\text { Control } \\
\text { Mean(SD) }\end{array}$ & $\begin{array}{c}\text { Sterilization } \\
\text { Mean(SD) }\end{array}$ & $\begin{array}{c}\text { p-value } \\
\text { Student's } \\
\text { t-test }\end{array}$ \\
\hline 15 & $0.016 \pm 0.0003$ & $0.020 \pm 0.0002$ & 0.10 \\
\hline 20 & $0.0034 \pm 0.003$ & $0.0032 \pm 0.0008$ & 0.67 \\
\hline 25 & $0.0050 \pm 0.0009$ & $0.0049 \pm 0.0009$ & 0.94 \\
\hline 30 & $0.0076 \pm 0.0006$ & $0.0080 \pm 0.0008$ & 0.36 \\
\hline 35 & $0.0091 \pm 0.0009$ & $0.0093 \pm 0.0014$ & 0.80 \\
\hline 40 & $0.019 \pm 0.130$ & $0.0086 \pm 0.012$ & 0.11 \\
\hline 45 & $0.018 \pm 0.0064$ & $0.015 \pm 0.002$ & 0.31 \\
\hline 50 & $0.012 \pm 0.0027$ & $0.0099 \pm 0.006$ & 0.51 \\
\hline 55 & $0.0114 \pm 0.0007$ & $0.011 \pm 0.0009$ & 0.06 \\
\hline 60 & $0.0138 \pm 0.0008$ & $0.0130 \pm 0.0003$ & 0.06 \\
\hline 70 & $0.0243 \pm 0.0028$ & $0.021 \pm 0.0019$ & 0.36 \\
\hline 80 & $0.020 \pm 0.019$ & $0.021 \pm 0.0024$ & 0.85 \\
\hline
\end{tabular}

Shapiro-Wilk test for normality of data. Levene's test for equality of variances. $p<0.05^{\star}$ indicates significant differences between both groups.

\section{DISCUSSION}

Management of asepsis is essential in all dental procedures to prevent cross-infections, post-treatment failures, unnecessary prescription of antibiotics, and complications that endanger the patient's life. Therefore, controlling microorganisms through sterilization of instruments or materials is crucial for the success of the procedures. Although Universities teach this concept, healthcare professionals or students many times do not consider the microbiological conditions of some materials used.

Paper points are one of the materials used without prior sterilization or disinfection, although their contamination has been demonstrated. This study found that $22 \%$ of the points collected were contaminated by facultative anaerobic bacteria; however, a significant relationship with the conditions under which they grew could not be determined. Pessoa et al., 2014 also reported point contamination regardless of the conditions they analyzed, including sealed, open, or manipulated packaging [10].

On the other hand, other studies have 
determined that there are conditions that cause point contamination, including the absence of previous sterilization, brand, and handling processes [7,9] For example, Ximenes et al., reported contamination in points of the same brand which were already sterilized compared with those that were sterilized after being opened [9]. Furthermore, several authors have detected contamination in specific brands, even when the points come in sealed packages which have been previously sterilized $[7,9,11]$. Similarly, Do Prado et al., 2012 reported contamination only in points coming from packages that remained open for a month [12].

Regarding the morphology of facultative anaerobic bacteria found in this study, grampositive bacilli without spores predominated, whereas gram-positive cocci and gram-positive bacilli with spores were less frequent. Among the microorganisms identified in endodontic infections, regardless of whether they are primary or secondary, facultative gram-positive anaerobic bacteria play a fundamental role in dental infections [13]. The gram-positive cocci found in this study were identified as $S$. epidermidis. This bacterium has been associated with infections such as dental abscesses [14], endocarditis [15], and bacteremia. It also shares characteristics with one bacterium frequently associated with endodontic failure, namely Enterococcus faecalis, owing to its ability to form biofilms [16] and its resistance to several antimicrobial agents [17].

Therefore, this study demonstrates the contamination of paper points used by students at the UCC clinics by bacteria that can adapt to conditions within obturated root canal, such as the absence of oxygen, indicating an interruption in the chain of asepsis during endodontic procedures. These data confirm the need to implement sterilization/disinfection protocols, which should not compromise the physical and chemical properties of paper points, especially absorption capacity, which is one of the most important features of these materials [10]. Various sterilization/disinfection methods have been used for paper points, such as dry heat, damp heat, or formaldehyde tablets. Because autoclave sterilization is the most widely used method in dentistry owing to its speed and efficiency, it was decided that this investigation would determine whether this method affects the points of one of the brands most commonly used by students. This study found that there is no change in this characteristic, which has been reported by other studies $[6,18,19]$.

Finally, it is important to clarify the argument of other authors that it is important to analyze the effect of sterilization on absorption capacity and to verify that there are no alterations causing the release of cellulose fibers, which can reach the periapical third, leading to rejection of the foreign body [18]. Therefore, we recommend performing a study to confirm whether there is a release of fibers after the sterilization cycles and also to determine the capacity to absorb other fluids.

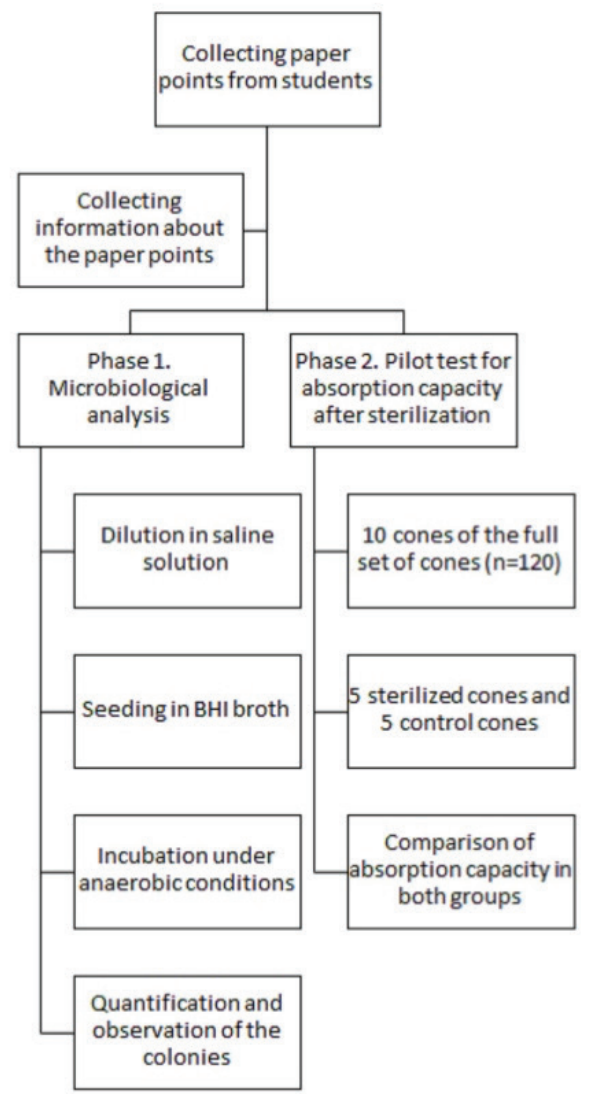

Figure 1 - Phases of the study conducted to determine the presence of facultative anaerobic bacteria in the paper points and to perform a pilot test to determine the effect of sterilization. 

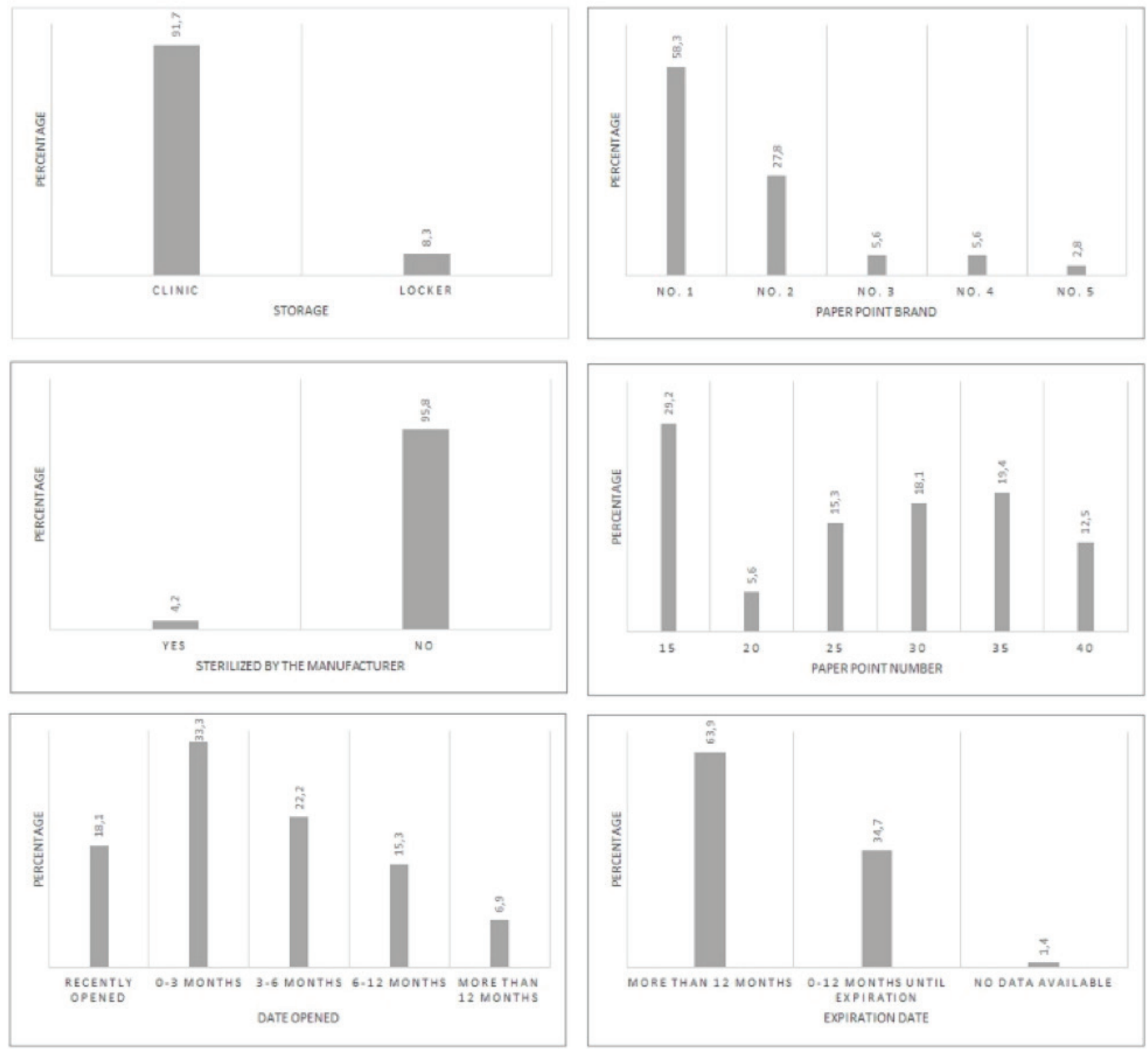

Figure 2 - Characteristics of the paper points analysed in this study. 

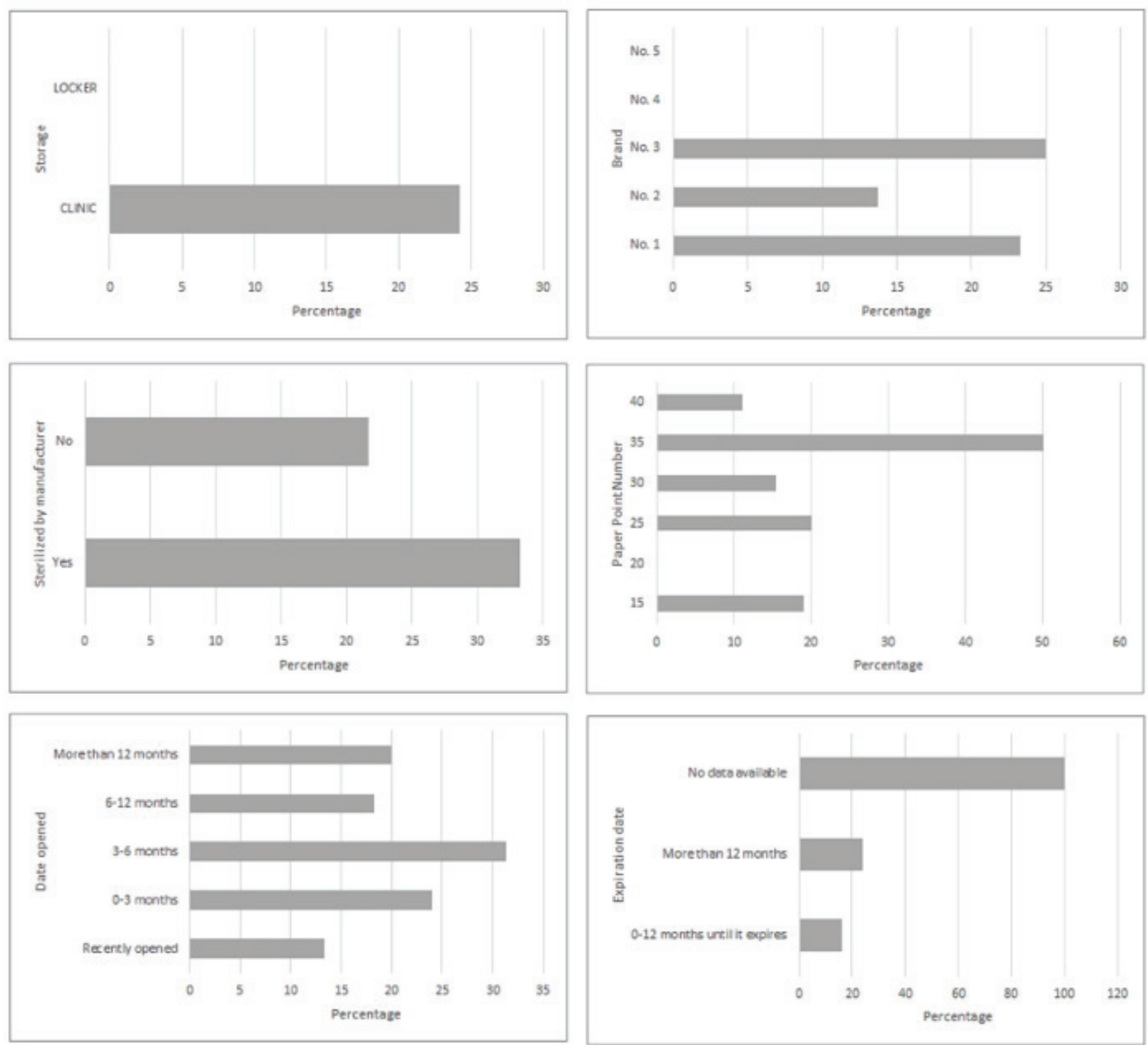

Figure 3 - Proportion of paper point contamination within each reported characteristic.

\section{CONCLUSIONS}

This study found that $22 \%$ of paper points used by students in the first semester of 2017 were contaminated by facultative anaerobic bacteria. The bacteria observed included grampositive bacilli and gram-positive cocci, among which $S$. epidermidis was identified. Furthermore, no association was found between the point conditions and contamination; therefore we recommend sterilizing/disinfecting paper points independently of the conditions evaluated. The pilot sterilization test performed in this study showed that it does not affect the absorption capacity of the points.

\section{Acknowledgment:}

We would like to thank the students who contributed by collecting the paper points and by analyzing the samples. 


\section{REFERENCES}

1. World Health Organization. Infection prevention and control. [Internet]. WHO [cited 2019 Feb 12]. Available from: https://www.who.int/ antimicrobial-resistance/global-action-plan/infection-prevention-control/ en/.

2. Centers for Disease Control and Prevention. Summary of infection prevention practices in dental settings: Basic expectations for safe care [Internet]. Atlanta, GA: Centers for Disease Control and Prevention, US Dept of Health and Human Services; 2016. [cited 2019 Feb 6]. Available from: https://www.cdc.gov/oralhealth/infectioncontrol/pdf/safe-care2. pdf.

3. Malmberg L, Björkner AE, Bergenholtz G. Establishment and maintenance of asepsis in endodontics - a review of the literature. Acta Odontol Scand. 2016;74(6):431-5. doi:10.1080/00016357.2016.1195508

4. Musani I, Goyal V, Singh A, Bhat C. Evaluation and comparison of biological cleaning efficacy of two endofiles and irrigants as judged by microbial quantification in primary teeth - an in vivo study. Int J Clin Pediatr Dent. 2009;2(3):15-22. doi:10.5005/jp-journals-10005-1013

5. Sakko M, Tjäderhane L, Rautemaa-Richardson R. Microbiology of root canal infections. Prim Dent J. 2016;5 (2):84-9. doi:10.1308/205016816819304231.

6. Aguiar CM, Torres T, Mendes DA, Farias B, Câmara AC. Effect of sterilization methods on the absorption capacity of absorbent paper points. Braz Dent Sci. 2012;15(1):27-32. doi: 10.14295/bds.2012.v15i1.737

7. Almeida MB, André MC, dos Santos P, de Oliveira T (2010). Avaliação da contaminação de cones de papel absorvente. Rev Bras Odontol. 2010; 67(1):81-5. doi: 10.18363/rbo.v67n1.p.81.

8. Pereira ER, Nabeshima CK, de Lima Machado ME. Analysis of contamination of endodontic absorbent paper points. Rev Odonto Cienc. 2011;26(1):56-60. doi: 10.1590/S1980-65232011000100013.

9. Ximenes R, Marques F, da Silva J, Amaral G, Sassone LM. In vitro analysis of microbial contamination of paper points. RSB0. 2014;11(4):336-9.
10. Pessoa de Andrade L, Chacon de Oliveira Conde N, Sponchiado Junior EC, Franco Marques AA, Pereira JV, Garcia LF. Contamination of absorbent paper points in clinical practice: a critical approach. Gen Dent. 2014;62(4):e38-e40.

11. Avendaño A. Verificación de la esterilidad de las puntas de papel absorbente utilizadas en la terapia endodôntica [Internet]. [cited 2019 Jan 15]. Availablrom:http://www.carlosboveda.com/Odontologosfolder/ odontoinvif tadoold/odontoinvitado3.htm

12. do Prado M, Duque TM, Gomes BPFA, Borges D0, Gusman HCS. Evaluation of cell pack paper points: a microbiological study. Dent Press Endod. 2012;2(2):42-6.

13. Gajan EB, Aghazadeh M, Abashov R, Salem Milani A, Moosavi Z. Microbial flora of root canals of pulpally-infected teeth: enterococcus faecalis a prevalent species. J Dent Res Dent Clin Dent Prospects. 2009;3(1):24-7. doi:10.5681/joddd.2009.007

14. Shweta, Prakash SK. Dental abscess: a microbiological review. Dent Res J (Isfahan). 2013;10(5):585-91.

15. Otto M. Staphylococcus epidermidis--the \&A39; accidental\&A39; pathogen. Nat Rev Microbiol. 2009;7(8):555-67. doi:10.1038/nrmicro2182.

16. 0\&A39;Gara JP, Humphreys H. Staphylococcus epidermidis biofilms: importance and implications. J Med Microbiol. 2001;50(7):582-7. doi:10.1099/0022-1317-50-7-582.

17. Otto M. Staphylococcus epidermidis pathogenesis. Methods Mol Biol. 2014;1106:17-31. doi: 10.1007/978-1-62703-736-5 2

18. Kubo CH, Gomes APM, Jorge AOC. Influência dos métodos de esterilização na capacidade e velocidade de absorção de diferentes marcas comerciais de cones de papel absorvente para endodontia. Rev Odontol UNESP 2000;29(1/2):113-27.

19. Victorino FR, Lukiantchuk M, Garcia LB, Bramante CM, Moraes IG, Hidalgo MM. Capacidade de absorção e toxicidade de cones de papel após esterilização. RG0. 2008;56(4):411-5.

\section{Dr. María del Pilar Angarita}

(Corresponding address)

Dentistry Program, Universidad Cooperativa de Colombia, Villavicencio, Colombia.

Carrera 35\#36-99, Villavicencio, Colombia.

E-mail: maria.angaritad@campusucc.edu.co

Date submitted: 2020 Feb 12

Accept submission: 2020 Mar 30 